Note

\title{
Reaction of sources of resistance to white mold to microsatellite haplotypes of Sclerotinia sclerotiorum
}

\author{
Miller da Silva Lehner ${ }^{1}$, Trazilbo José de Paula Júnior ${ }^{2 *}$, Rogério Faria Vieira², Renan Cardoso Limaํ, Bruno de Almeida Soares², \\ Rhaphael Alves Silva ${ }^{2}$
}

${ }^{1}$ Federal University of Viçosa - Plant Science Dept., Av. P.H. Rolfs, s/n - Campus Universitário - 36570-900 - Viçosa, MG - Brazil.

${ }^{2}$ Agricultural Research Institute of Minas Gerais (EPAMIG) Vila Gianetti, 47 - 36570-900 - Viçosa, MG - Brazil.

*Corresponding author <trazilbo@epamig.br>

Edited by: Claudio Marcelo Gonçalves de Oliveira

Received March 04, 2015

Accepted August 04, 2015
ABSTRACT: White mold caused by the fungus Sclerotinia sclerotiorum is the most yield-limiting disease of common bean in Brazil. To date, there has been no commercial cultivar resistant to this disease. In a greenhouse we evaluated white mold resistance sources (Cornell 605, A195 and G122) against eight isolates of S. sclerotiorum from five Brazilian states. A Brazilian cultivar (BRSMG Madrepérola) and a susceptible check (Beryl) were used as control. Treatments were arranged in factorial combinations $(5 \times 8)$ in a completely random design with four replicates. Disease severity was assessed on a rating scale of 1-to-9 together with lesion length, which was used to determine an area under the disease progress curve (AUDPC). Polymorphisms detected in ten microsatellite loci were used to assess variability between the isolates. Each isolate was a distinct haplotype; they formed a genetic tree with two clusters. One cluster was formed by three isolates collected from the states of Minas Gerais and São Paulo (southeastern); the others, by isolates from Paraná, Santa Catarina (southern), Goiás (Mid-western), and again, Minas Gerais. Genotype $\times$ isolate interaction was significant. In general, Beryl was more susceptible than BRSMG Madrepérola. Considering the AUDPC and/or the white mold reaction score, Cornell 605 exhibited more physiological resistance than BRSMG Madrepérola to seven isolates, A195 to five isolates, and G122 to two isolates. Our results suggest that Cornell 605 is the best source of resistance to white mold for the southern region, whereas Cornell 605 and A195 are somewhat superior to G122 for the southeastern and mid-western regions.

Keywords: Phaseolus vulgaris, common bean, crop breeding, variability

\section{Introduction}

Resistance to white mold caused by Sclerotinia sclerotiorum (Lib.) de Bary is a challenge to plant breeders. This pathogen has a necrotrophic lifestyle and secretes oxalic acid and a wide array of cell-wall-degrading enzymes to colonize plants (Bolton et al., 2006). Additionally, the genetic control of the disease is complex, because resistance is conditioned by both avoidance and physiological mechanisms (Schwartz and Singh, 2013).

Complete resistance to white mold is found only in non-host crops. With regard to the common bean (Phaseolus vulgaris L.), breeding for white mold resistance has advanced recently, especially in the United States, where several studies on the genetic mechanisms of resistance and breeding strategies have been carried out (Terán and Singh, 2009; Terán and Singh, 2010; Singh et al., 2014; Viteri and Singh, 2015) and a number of partially resistant lines have been released (Griffiths, 2009; Kelly et al., 2012; Miklas et al., 2014).

Recent studies concerning white mold resistance have been conducted in Brazil to identify sources of resistance (Carvalho et al., 2013; Souza et al., 2014; Lehner et al., 2015b) or understand the genetic control of resistance (Antonio et al., 2008; Carneiro et al., 2011). In a previous study (Lehner et al., 2015b), the physiological resistance of 20 putative sources of white mold resis- tance from the Bean White Mold Nursery (University of Nebraska, USA) was assessed. The lines A195, Cornell 605 and G122 were considered as the best sources of resistance to white mold for common bean breeding programs in Brazil. However, the physiological resistance of such genotypes was assessed using only one S. sclerotiorum isolate collected in Oratórios, in the state of Minas Gerais. Thus, this study aimed to assess the physiological resistance of the lines A195, Cornell 605 and G122 to eight genetically distinct isolates of $S$. sclerotiorum collected from the main producing regions of common bean in Brazil.

\section{Materials and Methods}

The experiment was conducted in a greenhouse located in Viçosa, in the state of Minas Gerais, Brazil. Five common bean genotypes (A195, Cornell 605, G122, Beryl, and BRSMG Madrepérola) and eight $S$. sclerotiorum isolates (Ss-2, Ss-44, Ss-115, Ss-136, Ss-192, Ss-219, Ss-313, and Ss-347) were used. Beryl was one of the most susceptible genotypes to white mold in our previous study (Lehner et al., 2015b) and was used in this study as a susceptible check. BRSMG Madrepérola is a Brazilian cultivar, susceptible to white mold in the field (Vieira et al., 2012) and with low physiological resistance (Lehner et al., 2015b). This cultivar was used as an intermedi- 
ate check. Eight isolates of S. sclerotiorum were collected from commercial fields between 2010 and 2013 from the following districts and states of Brazil: Ss-2 (Oratórios, Minas Gerais, 20²5'51 'S, 4248'21 ''W), Ss-44 (Paracatu, Minas Gerais, 16³9'38 'S, 4706'22 'W), Ss-115 (Patos de Minas, Minas Gerais, 18³4'44 'S, 46³1'04'" W), Ss-136 (Itaí, São Paulo, 2325'04 ''S, 4905'27 'W), Ss-192 (Corbélia, Paraná, 2447'56 ''S, 5318'25 ''W), Ss219 (Reserva do Iguaçu, Paraná, 2550'20 'S, 5201'40 'W), Ss-313 (Curitibanos, Santa Catarina, 2716'58 'S, 50³5'02 'W), and Ss-347 (Montividiu, Goiás, 17²15'20 'S, 5055'34 'W) (Figure 1A). Together, these states from the southeast (Minas Gerais and São Paulo), south (Paraná and Santa Catarina), and mid-western (Goiás) regions were responsible for about $55 \%$ of total bean production in Brazil in 2014-2015 (CONAB, 2015).

A sclerotium from each sampled field was randomly selected for obtaining the isolates. The isolates from Minas Gerais were purified by hyphal-tipping and those from the states of Goiás, São Paulo, Paraná, and Santa Catarina by a single ascospore as described by Lehner et al. (2015a). Isolates were genotyped using the microsatellite loci 7-2, 8-3, 9-2, 12-2, 13-2, 36-4, 42-4, 92-4, 106-4 and 114-4 (Sirjusingh and Kohn, 2001). PCR reactions were performed with Type-it Microsatellite PCR kit as described by the manufacturer (Qiagen). We used primers labeled with fluorescent dye (6-FAM, NED, HEX; Applied Biosystems) and an automatic sequencer ABI PRISM 3100 Genetic Analyser (Applied Biosystem) for measuring the size of the alleles (Lehner et al., 2015a). Each S. sclerotiorum isolate was assigned to a haplotype using GenoDive software (Meirmans and Tienderen, 2004). Relationships between haplotypes were assessed based on Bruvo's genetic distance (Bruvo et al., 2004) followed by a hierarchical cluster analysis in accordance with the Ward criterion (Ward, 1963). Both analyses were conducted in the $\mathrm{R}$ program using the Poppr package (Kamvar et al., 2014).

Seeds were rolled up in germination paper saturated with water and germinated in the dark at ambient temperature for $48 \mathrm{~h}$. Afterwards, three seeds were selected and planted at $1-\mathrm{cm}$ depth in $3-\mathrm{L}$ pots containing the substrate Tropstrato HT Hortaliças (Vida Verde, Mogi-Mirim, in the state of São Paulo, Brazil). The temperature in the greenhouse ranged from $16{ }^{\circ} \mathrm{C}$ to $29^{\circ} \mathrm{C}$ and relative humidity was maintained at over $80 \%$ by a sprinkler irrigation system. Pathogen inoculation was performed using the straw test methodology (Petzoldt and Dickson, 1996) with minor modifications (Lehner et al., 2015b). Treatments were arranged in factorial combinations of five common bean genotypes (A195, Cornell 605, G122, Beryl, and BRSMG Madrepérola) and eight $S$. sclerotiorum isolates (Ss-2, Ss-44, Ss-115, Ss-136, Ss-192, Ss-219, Ss-313, and Ss-347). A completely random design with four replicates was used. Each replicate was a pot with three plants.

The disease severity was evaluated in individual plants at 14 days after inoculation (DAI) using the 1-to-9 rating scale where $1=$ no infection, 2 = infection occurred but invasion of the first internode $<2 \mathrm{~cm}, 3=$ invasion progressed $>2 \mathrm{~cm}$ but did not reach the first node, $4=$ invasion reached the first node but no further, $5=$ invasion passed the first node but progressed $<2$ $\mathrm{cm}$ on the second internode, $6=$ invasion of the second internode $>2 \mathrm{~cm}$ but did not reach the second node, 7 $=$ invasion reached the second node but no further, $8=$ invasion passed the second node but progressed $<2 \mathrm{~cm}$ on the third internode and no plant death, and $9=$ inva-
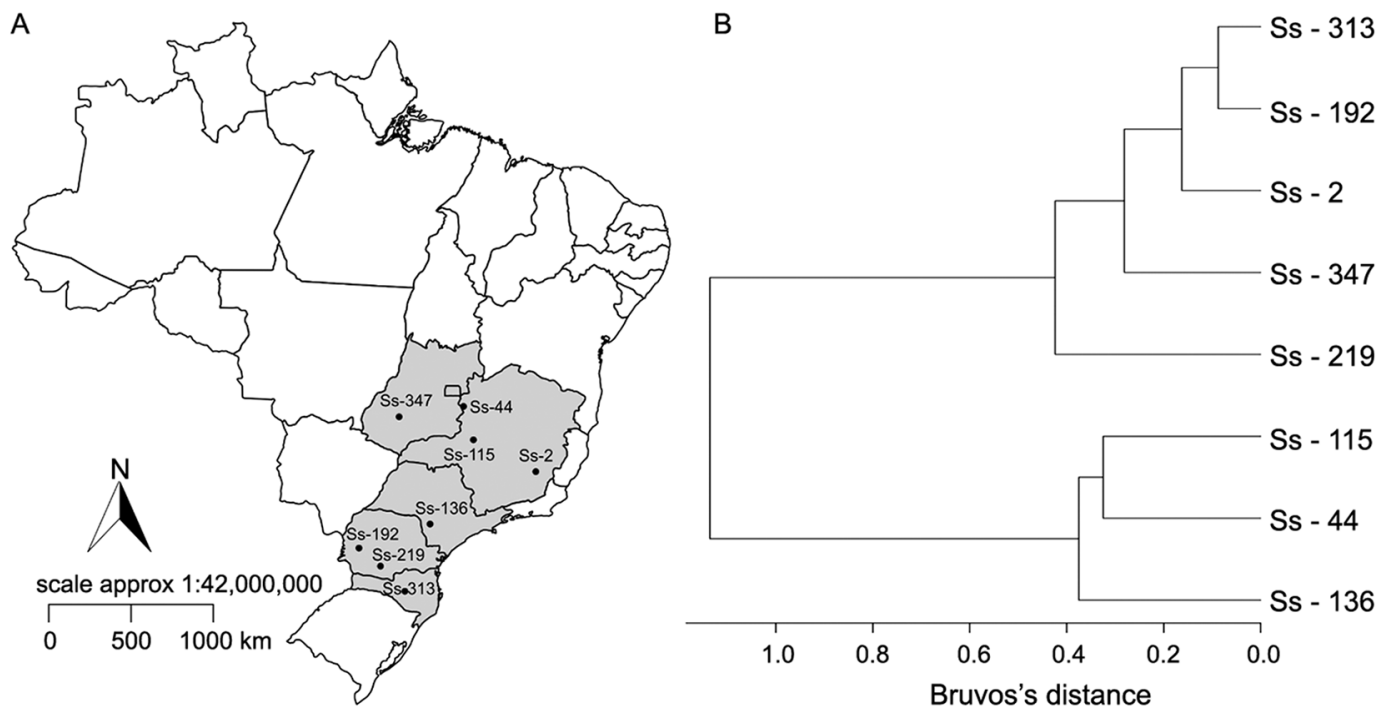

Figure 1 - (A) Dots in the Brazilian states shown in gray are the sites where eight Sclerotinia sclerotiorum isolates were collected. (B) Dendrogram based on Bruvo's genetic distance (Bruvo et al., 2004) of the microsatellite data according to the Ward criterion (Ward, 1963). 
sion of the third internode $>2 \mathrm{~cm}$ or plant death (Terán et al., 2006). Disease severity was also evaluated using length of lesions at 2, 4, 6, 7, 8 and 14 DAI. Using these data, we calculated the area under the disease progress curve (AUDPC) according to Shaner and Finney (1977). Data were analyzed for normality with Lilliefors's test using the $\mathrm{R}$ program. The disease severity estimated using the 1-to- 9 rating scale did not meet the normality assumption. Thus, it was transformed using $\log 10 / \mathrm{x}+$ 1). Analysis of variance was conducted and treatment means were separated using an LSD test at $p<0.05$. Both analyses were conducted using the $\mathrm{R}$ program.

\section{Results and Discussion}

Each S. sclerotiorum isolate was a distinct haplotype. Bruvo's genetic distance between haplotypes ranged from 0.087 to 0.615 forming a genetic tree with two clusters (Figure 1B). One cluster included the isolates Ss-44, Ss-115, and Ss-136 from the southeastern states (Minas Gerais and São Paulo). The second cluster included three isolates (Ss-192, Ss-219, and Ss-313) from the southern states (Paraná and Santa Catarina), one from the state of Goiás (Ss-347), and one from the state of Minas Gerais (Ss-2).

The interaction between $S$. sclerotiorum isolates and common bean genotypes was significant as regards white mold reaction score $(p<0.001$, Figure 2A) and AUDPC ( $p=0.011$, Figure $2 \mathrm{~B})$. These results suggest that resistance of common bean genotypes to white mold may vary according to the $S$. sclerotiorum isolate. Pascual et al., (2010) also found significant common bean genotype $\times S$. sclerotiorum isolates interaction, but Otto-Hanson et al., (2011) did not. The different results may be due to the variability of isolates and/or cultivars, inoculation method, and environmental conditions under which the experiments were carried out.

The average white mold reaction score varied from 5.0 (Cornell 605) to 8.3 (Beryl) and the average AUDPC varied from 59 (Cornell 605) to 141 (Beryl) across the isolates (data not shown). In general, Beryl was the most susceptible genotype to white mold (Figure 2). On average, the white mold reaction scores of Cornell 605, A195 and G122 across the eight isolates were $40 \%, 34 \%$ and $22 \%$ lower than those for the susceptible check Beryl; for AUDPC, they were $58 \%$, $43 \%$ and $46 \%$ lower, respectively.

Beryl and the Brazilian cultivar BRSMG Madrepérola did not differ for white mold reaction score or AUPDC caused by the isolates Ss-136, Ss-313, and Ss347. Cornell 605 had lower means $(p<0.05)$ of white mold reaction score than BRSMG Madrepérola for all isolates, except for the Ss-2 isolate (Figure 2A). However, AUPDC means of these genotypes were different $(p<0.05)$ only for the isolates Ss-192 and Ss-219, both from Paraná, and for the Ss-347 isolate, from Goiás (Figure 2B). A195 had lower white mold reaction score than BRSMG Madrepérola $(p<0.05)$ for the isolates Ss-
115 (Minas Gerais), Ss-136 (São Paulo), Ss-192 (Paraná), Ss-219 (Paraná,) and Ss-347 (Goiás) (Figure 2A). However, these genotypes only differed in AUDPC $(p<$ 0.05) for the isolate Ss-115 (Figure 2B). G122 was more resistant to white mold than BRSMG Madrepérola for the isolates Ss-136 (Figure 2A) and Ss-347 (Figure 2B). A195 had higher levels of resistance to white mold than G122 when the plants were inoculated with the isolates Ss-115, Ss-192, and Ss-347 (Figure 2A). Cornell 605 had higher levels of resistance to white mold than A195 when the plants were inoculated with the isolates Ss-219 (Figure 2A and 2B) and SS-313 (Figure 2B), both from southern Brazil.

In our previous study (Lehner et al., 2015b), Cornell 605, A195 and G122 showed high-yielding potential in the field and intermediate resistance or resistance to anthracnose, angular leaf spot, rust, and fusarium wilt. Furthermore, they exhibited a high level of physiological resistance to a specific isolate of $S$. sclero-
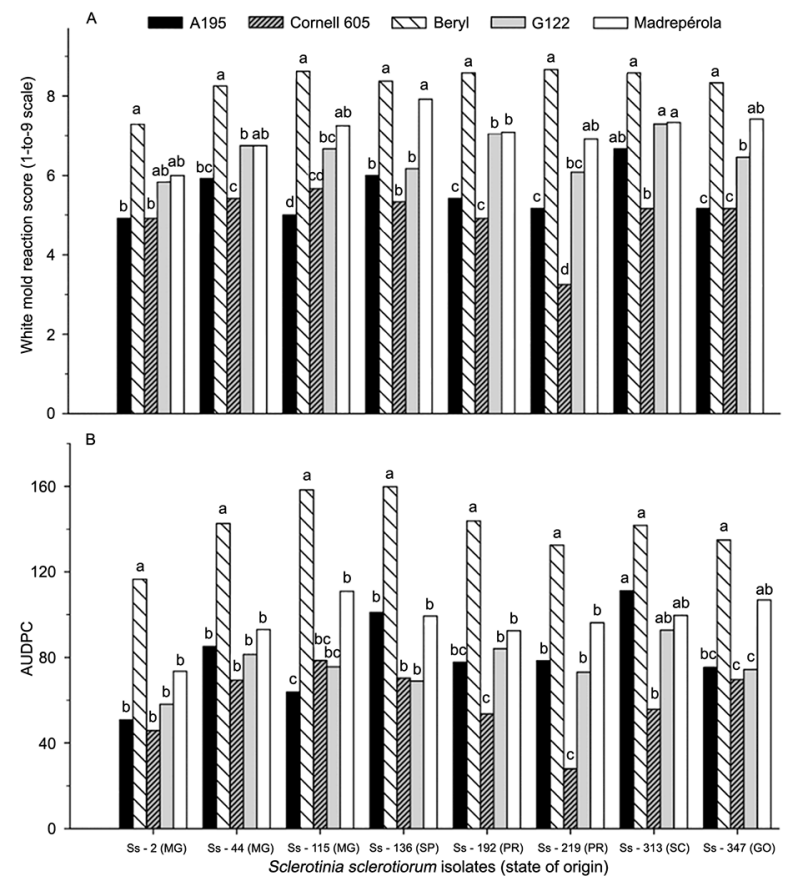

Figure 2 - Mean white mold reaction scores evaluated $14 \mathrm{~d}$ after inoculation $(A)$ and mean area under the disease progress curve (AUDPC) from 2 to $14 \mathrm{~d}$ after inoculation (B) of eight Sclerotinia sclerotiorum isolates onto five common bean genotypes using the straw test. These isolates were collected from five Brazilian states: $M G$ = Minas Gerais; $S P=$ São Paulo; $P R=$ Paraná; $S C=$ Santa Catarina; and G0 = Goiás. A195, Cornell 605 and G122 are white mold resistance sources; Beryl is a susceptible check; and BRSMG Madrepérola is a Brazilian cultivar susceptible to white mold in field tests and with low physiological resistance. In panel A data were transformed using $\log 10(x+1)$ before analysis, but untransformed means are presented. The bars labeled with different letters within each isolate are significantly different ( $p \leq$ 0.05, LSD). 
tiorum, compared with other American and Brazilian common bean lines. Cornell 605, A195 and G 122 have determinate growth habit and upright plants (Type I). This characteristic facilitates mechanical harvesting. Furthermore, it is an important avoidance mechanism, since it minimizes contact between plants within and between rows and propitiates sunlight penetration and air circulation in the plant canopy, disfavoring white mold development (Miklas et al., 2013). The results of this study indicate that the physiological resistance of Cornell 605, A195 and G122 is effective against distinct genotypes of $S$. sclerotiorum collected from the main producing regions of common bean in Brazil.

Although plants of Cornell 605, A195 and G122 have some desirable agronomic attributes, the grain characteristics are not attractive to the Brazilian market. Cornell 605 is a light red kidney common bean (Griffiths, 2009), A195 has large opaque beige seeds (Singh et al., 2007) and G 122 belongs to the cranberry common bean class (Viteri and Sigh, 2015). In Brazil the "carioca" grain type (medium-sized cream-colored grains with brown stripes) is the most consumed common bean class (about $70 \%$ ). Therefore, the greatest challenge from now on is to incorporate the white mold resistance found in Cornell 605, A195 or G 122 in the elite cultivars of "carioca" grain type.

G122 is a well-known source of resistance to white mold abroad (Griffiths, 2009; Miklas et al., 2014; Singh et al., 2014; Viteri and Singh, 2015) and recently has been used in breeding programs in Brazil (Carneiro et al., 2011; Carvalho et al., 2013). The physiological resistance present in G122 is controlled by one gene with a predominance of additive effects, which facilitates the use of this line in breeding programs (Carneiro et al., 2011). Common bean lines exhibiting good levels of physiological resistance to white mold and commercially favorable grain type were recently obtained from backcrossing between G122 and an elite cultivar of "carioca" grain type (Carvalho et al., 2013). The performance of these lines in the field, however, was not assessed.

A195 has been used as a donor parent in breeding programs aimed at white mold resistance mainly in the USA (Terán and Singh, 2009; Terán and Singh, 2010). The white mold resistance present in this line is monogenic dominant in the field and recessive in the greenhouse (Genchev and Kiryakov, 2002). The use of Cornell 605 for improving white mold resistance is still incipient.

In this study, only a few isolates from each region were assessed. Thus, caution must be applied, because the populations of $S$. sclerotiorum are variable, although at low levels under Brazilian conditions (Lehner et al., 2015a). In general, our results suggest that Cornell 605 is the most appropriate source of physiological resistance to white mold for the southern region, whereas Cornell 605 and A195 are somewhat superior to G122 for the mid-western and southern regions.

\section{Acknowledgements}

Miller S. Lehner, Trazilbo J. Paula Júnior and Rogério F. Vieira were supported by the Brazilian National Council for Scientific and Technological Development (CNPq, Brasília, Brazil) Renan C. Lima was supported by the Coordination for the Improvement of Higher Level Personnel Agency (CAPES). This research was supported by $\mathrm{CNPq}$ and the Minas Gerais State Foundation for Research Support (FAPEMIG - Belo Horizonte, Brazil).

\section{References}

Antonio, R.P.; Santos, J.B.; Souza, T.P.; Carneiro, F.F. 2008. Genetic control of the resistance of common beans to white mold using the reaction to oxalic acid. Genetics and Molecular Research 7: 733-740.

Bolton, M.D.; Thomma, B.P.H.J.; Nelson, B.D. 2006. Sclerotinia sclerotiorum (Lib) de Bary: biology and molecular traits of cosmopolitan pathogen. Molecular Plant Pathology 7: 1-16.

Bruvo, R.; Michiel, N.K.; D'Souza, T.G.; Schulenburg, H. 2004. A simple method for the calculation of microsatellite genotype distances irrespective of ploidy level. Molecular Ecology 13: 2101-2106.

Carneiro, F.F.; Santos, J.B.; Gonçalves, P.R.C.; Antonio, R.P.; Souza, T.P. 2011. Genetics of common bean resistance to white mold. Crop Breeding and Applied Biotechnology 11: 165-173.

Carvalho, R.S.B.; Lima, I.A.; Alves, F.C.; Santos, J.B. 2013. Selection of carioca common bean progenies resistant to white mold. Breeding and Applied Biotechnology 13: 172-177.

Companhia Nacional de Abastecimento [CONAB]. 2015. Monitoring Brazilian grain harvest. = Acompanhamento de safra Brasileira de grãos. Available at: www.conab.gov.br. [Accessed April 30, 2014] (in Portuguese).

Genchev, D.; Kiryakov, I. 2002. Inheritance of resistance to white mold disease (Sclerotinia sclerotiorum (Lib.) de Bary) in the breeding line A 195 of common bean (Phaseolus vulgaris L.). Bulgarian Journal of Agricultural Science 8: 181-187.

Griffiths, P.D. 2009. Release of Cornell 601-606: common bean breeding lines with resistance to white mold. HortScience 44: 463-465.

Kamvar, Z.N.; Tabima, J.F.; Grunwald, N.J. 2014. POPPR: an $\mathrm{R}$ package for genetic analysis of populations with clonal, partially clonal, and/or sexual reproduction. PeerJ 2: e281.

Kelly, J.D.; Mkwaila, W.; Varner, G.V.; Cichy, K.A.; Wright, E.M. 2012. Registration of 'Eldorado' Pinto Bean. Journal of Plant Registrations 6: 233-237.

Lehner, M.S.; Paula Júnior, T.J.; Hora Júnior, B.T.; Teixeira, H.; Vieira, R.F.; Carneiro, J.E.S.; Mizubuti, E.S.G. 2015a. Low genetic variability in Sclerotinia sclerotiorum populations from common bean fields in Minas Gerais state, Brazil, at regional, local and micro scales. Plant Pathology 64: 921-931.

Lehner, M.S.; Teixeira, H.; Paula Júnior, T.J.; Vieira, R.F.; Lima, R.C.; Carneiro, J.E.S. 2015b. Adaptation and resistance to diseases in Brazil of putative sources of common bean resistance to white mold. Plant Disease 99: 1098-1103. 
Meirmans, P.G.; Tienderen, P.H. van. 2004. GENOTYPE and GENODIVE: two programs for the analysis of genetic diversity of asexual organisms. Molecular Ecology Notes 4: 792-794.

Miklas, P.N.; Kelly, J.D.; Steadman, J.R.; McCoy, S. 2014. Registration of Pinto bean germplasm line USPT-WM-12 with partial white mold resistance. Journal of Plant Registrations 8: 183-186.

Miklas, P.N.; Porter, L.D.; Kelly, J.D.; Myers, J.M. 2013. Characterization of white mold disease avoidance in common bean. European Journal of Plant Pathology 135: 525-543.

Otto-Hanson, L.; Steadman, J.R.; Higgins, R.; Eskridge, K.M. 2011. Variation in Sclerotinia sclerotiorum bean isolates from multisite resistance screening locations. Plant Disease 95: 1370-1377.

Pascual, A.; Campa, A.; Pérez-Vega, E.; Giraldez, R.; Miklas, P.N.; Ferreira, J.J. 2010. Screening common bean for resistance to four Sclerotinia sclerotiorum isolates collected in northern Spain. Plant Disease 94: 885-890.

Petzoldt, R.; Dickson, M.H. 1996. Straw test for resistance to white mold in beans. Annual Report of the Bean Improvement Cooperative 39: 142-143.

Schwartz, H.F.; Singh, S.P. 2013. Breeding common bean for resistance to white mold: a review. Crop Science 53: 1832-1844.

Shaner, G.; Finney, R.E. 1977. The effect of nitrogen fertilization on the expression of slow-mildewing resistance in Knox wheat. Phytopathology 67: 1051-1056.

Singh, S.P.; Schwartz, H.F.; Viteri, D.; Terán, H.; Otto, K. 2014. Introgressing white mold resistance from Phaseolus coccineus PI 439534 to common bean pinto bean. Crop Science 54: 1-7.
Singh, S.P.; Terán, H.; Lema, M.; Schwartz, H.F.; Miklas, P.N. 2007. Registration of white mold resistant dry bean germplasm line A 195. Journal of Plant Registration 1: 62-63.

Sirjusingh, C.; Kohn, L.M. 2001. Characterization of microssatelites in the fungal plant pathogen, Sclerotinia sclerotiorum. Molecular Ecology Notes 1: 267-269.

Souza, D.A.; Pereira, F.A.C.; Dias, J.A.; Leite, M.E.; Santos, J.B. 2014. Reaction of common bean progenies to white mold derived from recurrent selection. Ciência Rural 44: 583-587.

Terán, H.; Singh, S.P. 2009. Gamete selection for improving physiological resistance to white mold in common bean. Euphytica 167: 271-280.

Terán, H.; Singh, S.P. 2010. Recurrent selection for physiological resistance to white mould in dry bean. Plant Breeding 129: 327333.

Terán, H.; Lema, M.; Schwartz, H.F.; Duncan, R.; Gilbertson, R.; Singh, S.P. 2006. Modified Petzoldt and Dickson scale for white mold rating of common bean. Annual Report of Bean Improvement Cooperative 49: 115-116.

Vieira, R.F.; Paula Júnior, T.J.; Teixeira, H.; Carneiro, J.E.S.; Cardoso, R.L.; Queiroz, M.V.; Prado, A.L. 2012. Lines from Brazilian dry bean breeding programs with white mold resistance. Annual Report of the Bean Improvement Cooperative 55: 155-156.

Viteri, D.M.; Singh, S.P. 2015. Inheritance of white mold resistance in an Andean common bean A 195 and its relationship with Andean G 122. Crop Science 55: 44-49.

Ward, J.H. 1963. Hierarchical grouping to optimize an objective function. Journal of the American Statistical Association 58: 236-244. 